\title{
Gender, Intra-Household Dynamics, and Household Hurricane Preparedness: An Exploratory Study Employing a Dyadic Interview Approach
}

\author{
Li-San Hung ${ }^{1}$
}

Published online: 5 February 2018

(C) The Author(s) 2018. This article is an open access publication

\begin{abstract}
This exploratory study targets married, heterosexual couples living in Sarasota County, Florida and uses a dyadic interview approach to understand how the interactions of married couples, or intra-household dynamics, could affect household hurricane preparedness. Interview results reveal that couples consider household hurricane preparedness to be a joint process between husband and wife, but in many cases, partners do not have the same opinions about these preparations. This study also shows the relations between household hurricane preparedness and household division of labor, and how the tendency of wives to prioritize relational preparedness activities could be an answer to understanding why some quantitative studies show that females have lower preparedness levels than males. Other potential problems with this previous research, including the selection of survey participants and the measurement of household hurricane preparedness, are likewise discussed.
\end{abstract}

Keywords Dyadic interviews · Gender · Household decision making · Household hurricane preparedness · Intra-household dynamics

\section{Introduction}

Recognizing the need to minimize damage from natural hazards, emergency managers and community practitioners spend considerable time promoting household natural

\section{Li-San Hung}

lisanh23@gmail.com

1 Department of Geography, Pennsylvania State University, University Park, State College, PA 16802, USA hazard preparedness. In academe, various scholars have explored the underlying factors that contribute to household natural hazard preparedness (Lindell and Hwang 2008; Baker 2011; Becker et al. 2012). One of the less explored topics in household natural hazard preparedness, however, is how intra-household dynamics or gender dynamics affect the decision making of households with regard to natural hazard preparedness (Hung 2017). This study consequently relied on an interview-based qualitative approach to show how intra-household dynamics and gender dynamics influence household hurricane preparedness. The study also discusses some of the problems observed in many quantitative studies on household natural hazard preparedness, including the selection of survey participants and the measurement of household hurricane preparedness. It begins with a review of the literature on household-level natural hazard preparedness.

\section{Household Natural Hazard Preparedness}

Given the significant impact of natural hazards on human society, one of the main goals of emergency management is to ensure that individuals and households have the resources necessary to cope with such disasters and maintain basic levels of functioning during and immediately after the disaster events (Paton 2003; Paton et al. 2005; Lindell 2013). Helping households prepare for natural hazards is an important task for emergency management personnel.

Scholars are similarly eager to understand the underlying factors that promote household natural hazard preparedness. Research has indicated the importance of psychological, cognitive, social, political, ecological, and personal factors in determining a household's level of 
natural hazard preparedness (Hung 2017). For a detailed discussion of these factors, see Paton (2014).

Household natural hazard preparedness research has been conducted in diverse research settings (for example, in different countries with different cultures) and for various types of natural hazards: earthquakes (Lindell and Perry 2000), hurricanes (Baker 2011), bushfires (Paton et al. 2006), and tsunamis (Paton et al. 2008). Common to these studies is the conclusion that, in general, households are not well-prepared for natural hazards (Kohn et al. 2012; Levac et al. 2012). One of the possible problems underlying this conclusion is the paucity of standard measurements for household natural hazard preparedness. In the case of household hurricane preparedness (Table 1), for example, studies have adopted different lists of various scopes to capture household engagement with preparedness items and activities. Because of this variety of measures, it is hard to compare levels of preparedness across studies.

Another common component of these studies is their adoption of a quantitative-usually survey-based-approach. Most, if not all, of these survey-based investigations ask one adult in the household to answer the questions posed (for example, Russell et al. 1995; Lindell and Prater 2002; DeBastiani et al. 2015). In some studies, the head of the household is specifically asked to fill out the survey (Grothmann and Reusswig 2006; Basolo et al. 2009); in others, the person who is supposed to fill out the survey is not specified. Surveying one person per household, however, overlooks the possible influence of other household members on decisions regarding household natural hazard preparedness (Hung 2017). As studies on household decision making have shown (Davis 1976; Belch et al. 1985; Commuri and Gentry 2000; Lee and Beatty 2002; Kang and Hsu 2005), household members do not always have the same opinions, and, in many cases, decisions are made jointly by household members. For example, studies have captured joint decision-making processes for household travel behaviors (Mottiar and Quinn 2004), the buying of cars (Davis 1976), and the purchasing of homes (Blood and Wolfe 1960; Davis and Rigaux 1974). For further discussion, see Davis (1976) and Hung (2017).

The gender dynamics of household natural hazard preparedness cannot be overlooked, either. O'Brien and Atchison (1998) analyzed a survey distributed after the 1989 Loma Priesta earthquake and found gender differences in terms of aftershock earthquake preparedness behaviors. Females were more likely than males to seek information about earthquakes and their aftershocks, read available earthquake information, believe damaging aftershocks would occur, take actions to get ready for aftershocks, make household items safer, develop emergency plans for aftershocks, and prepare for aftershocks. Males were more likely than females to provide assistance outside of the household, including helping with search and rescue missions and directing traffic. In another study, Mulilis (1999) reported that university students seem to engage in different types of earthquake-preparedness activities, depending on gender: "tool-type" preparedness items are typically gendered as masculine, household-preparedness activities are often gendered as feminine, and some preparedness items-whether tool, household, or medical in orientation-are gendered as androgynous. Russell et al. (1995) found that gender differences are shown in some earthquake-preparedness behaviors, but Basolo et al. (2009) found no gender differences in either earthquakepreparedness or hurricane-preparedness behaviors.

Some studies have suggested that females are more prepared for hazards than males (Mahdaviazad and Abdolahifar 2014), but others have maintained that females are less prepared than males (Lemyre et al. 2007; Levac et al. 2012). Most of the research on the relationship between gender and household natural hazard preparedness falls into the methodological trap of using individual-level data (in this case gender) to predict household-level natural hazard preparedness (Hung 2017). If only one person in the household is surveyed, investigators also do not know if that individual is the primary decision maker in determining household natural hazard preparedness. Kirschenbaum's quantitative study (2006) treats household natural hazard preparedness as a household-level decision-making behavior and tries to predict levels of preparedness using household-level predictors. Kirschenbaum found that within a household, the gendered division of labor and family relationships affect how decisions regarding household natural hazard preparedness are made. He also showed that family relationships explain the level of household natural hazard preparedness.

Although practitioners and scholars have emphasized the importance of household natural hazard preparedness in reducing the damage caused by natural hazards, research has suggested that households are usually ill-prepared to face such hazards. This conclusion, however, is problematic because there is no standard measurement for natural hazard preparedness. In addition to presenting a methodological issue, use of individual-level data to predict household-level natural hazard preparedness suggests a neglect of intra-household and gender dynamics.

In this exploratory study, I tackle some of the problems raised above. More specifically, I show how intra-household dynamics and gender dynamics influence household hurricane preparedness. Although the sample sizes in this study are small, and many of the participants indicated that they have not actually experienced hurricane hazards- the type of natural hazard this study considers, the preliminary results suggest that in many cases, at least for heterosexual married couples, household natural hazard preparedness is 
Table 1 Selected studies on household natural hazard preparedness: preparedness index

\begin{tabular}{|c|c|c|}
\hline Study & Number of items and activities & List of items and activities \\
\hline \multirow[t]{2}{*}{ Baker (2011) } & Current preparedness: 8 & $\begin{array}{l}\text { Non-perishable food for the entire household for } 3 \text { days } \\
\text { A flashlight or lantern with batteries that would last at least } 3 \text { days } \\
\text { A battery-powered radio with batteries that would last at least } 3 \text { days } \\
\text { Important prescription medicines for everyone in the household for at least } 3 \text { days } \\
\text { Three gallons of drinkable water in containers for each person in the household } \\
\text { Important papers such as insurance policies, wills, bank accounts, and family records on } \\
\text { hand and quickly accessible } \\
\text { An outdoor grill for cooking and fuel or charcoal for it } \\
\text { A generator and at least a 3-day supply of fuel for it }\end{array}$ \\
\hline & Recent preparedness: 10 & $\begin{array}{l}\text { The above } 8 \text {, Plus } \\
\text { How much ice did you have on hand per person? (number of } 8-10 \mathrm{lb} \text {. bags) } \\
\text { How much gas did you have in your car? ( } 1 / 4 \text { tank or less, } 1 / 2 \operatorname{tank}, 3 / 4 \operatorname{tank} \text {, full or nearly } \\
\text { full tank) }\end{array}$ \\
\hline $\begin{array}{l}\text { Horney et al. } \\
\qquad(2008)\end{array}$ & 2 & $\begin{array}{l}\text { An evacuation plan for their household } \\
\text { A disaster supply kit that included at least } 3 \text { days of food and water for each household } \\
\text { member }\end{array}$ \\
\hline \multirow[t]{2}{*}{$\begin{array}{l}\text { Kim and Kang } \\
\text { (2010) }\end{array}$} & Pre-hurricane preparedness: 8 & $\begin{array}{l}\text { Talked in person with other people about the hurricane } \\
\text { Shopped for emergency foods or materials } \\
\text { Called others to talk about the hurricane } \\
\text { Tried to finish up some work before the hurricane } \\
\text { Helped other neighbors or friends to get prepared for the hurricane } \\
\text { Browsed websites to get information about the hurricane } \\
\text { Prepared the house } \\
\text { E-mailed others to talk about the hurricane }\end{array}$ \\
\hline & $\begin{array}{l}\text { During-hurricane preparedness: } \\
\quad 6\end{array}$ & $\begin{array}{l}\text { Called others to see if they were OK } \\
\text { Browsed websites to know what was going on } \\
\text { Sent e-mails to let other people know I was OK } \\
\text { Stayed with other neighbors or friends } \\
\text { Sent e-mails to other people to let them know I was OK and sent e-mails to other people to } \\
\text { check if they were OK }\end{array}$ \\
\hline \multirow[t]{4}{*}{$\begin{array}{l}\text { Basolo et al. } \\
\text { (2009) }\end{array}$} & \multicolumn{2}{|l|}{$\begin{array}{l}3 \text { Dichotomous categories of } \\
\text { preparedness: }\end{array}$} \\
\hline & Family plan & Family plan: $1=$ Has a plan, $0=$ no plan \\
\hline & Supplies & $\begin{array}{l}\text { Supplies: } 1=\text { Has all } 13 \text { items on hand (items not specified), } 0=\text { does not have all items } \\
\text { on hand }\end{array}$ \\
\hline & Shut off utilities & Shut off utilities: $1=$ Knows how to shut off utilities, $0=$ does not know \\
\hline
\end{tabular}

not determined by one person; spouses do not necessarily have the same ideas about household natural hazard preparedness. I also describe how household divisions of labor might influence levels of household natural hazard preparedness.

To date, Proudley (2008) is the only qualitative study that has a research focus similar to that of this study. Her research was based on interviews with couples and families who lived in areas affected by the 2005 Wangary bushfire (Eyre Peninsula bushfire) in Australia. She reported that for some couples, responses to bushfires represented mutual decisions, but that for others, especially stay-at-home wives, bushfires required them to be the sole crisis decision maker. This study also stressed how household roles (that is, household divisions of labor) affected couples' behaviors when facing bushfires, noting that "the roles that people have within the family unit play a major part in what family members do, how they behave and respond during a crisis" (Proudley 2008, p. 42). Proudley advocated use of the family unit in approaching bushfire research and argued that studies of conflict and cohesion within families, as well as of family decision making, can shed light on 
family dynamics in relation to decision making during a crisis. While this study considers issues similar to those addressed in Proudley (2008) and both studies stress the importance of family dynamics or intra-household dynamics in household decision making during disasters, Proudley's (2008) research is centered on bushfire disasters, and this study is focused on hurricane hazards. Yet, although Proudley's (2008) study was published nearly 10 years ago, other researchers and practitioners have continued to overlook her work and the importance of family dynamics when facing disasters.

This article redirects attention to the key concern of family dynamics in disaster decision making, and uses a unique dyadic interview approach to investigate the importance of intra-household dynamics and gender dynamics when assessing household decision making regarding natural hazard preparedness.

\section{Methodology}

A qualitative approach is used to address this study's research objectives. ${ }^{1}$ Qualitative methods are not often used in natural hazard preparedness studies-the few examples include Allen (2006) and Carter-Pokras et al. (2007)_but qualitative approaches are especially suitable for answering "how and why" research questions (McGee and Russell 2003). For example, studies that reveal the process or dynamics of a particular issue could be better achieved by qualitative than quantitative research methods (McIvor and Paton 2007).

Heterosexual married couples living in Sarasota County, Florida, were the research target of this study because, statistically speaking, they represent the most common type of couple in the United States. ${ }^{2}$ As in the studies of other hazard researchers, the present study used snowball methods to recruit interviewees (Jóhannesdóttir and Gísladóttir 2010; Parsizadeh et al. 2015). Given that this study is exploratory and its goal is to reveal the influence of intrahousehold dynamics on household natural hazard preparedness, this article does not seek to generalize to a larger population but rather to provide a detailed discussion of particular cases (Newman 2000; Jóhannesdóttir and Gísladóttir 2010). But to increase the diversity of the sample, I started with four distinct entry points based on personal contacts in Sarasota County (that is, four local

\footnotetext{
1 This study was part of my Ph.D. dissertation. See Hung (2016). A mixed-method study, some of the quantitative results from this research were published previously in Hung (2017).

2 Based on 2010 Census data, husband-wife family households account for $48.4 \%$ of total households in the United States, which is the relative majority type of all household types (U.S. Census Bureau 2010).
}

contacts with different characteristics). Overall, 13 interviews were conducted. The 13 couples were interviewed in a semistructured style during two periods: 11-14 June 2015 and 28 July-5 August 2015. I interviewed each couple together in places they had chosen, typically in their homes. Each of the interviews lasted between 30 and $80 \mathrm{~min}$.

There is a growing interest in the dyadic interview format (Thompson and Walker 1982; Morris 2001; Morgan et al. 2013; Caldwell 2014). According to Eisikovits and Koren (2010), there are five types of dyadic interview datacollection modalities: separate interviews, separate interviews performed simultaneously by different interviewers, joint interviews, both separate and joint interviews with the same participants, and separate interviews with some informants and joint interviews with others. After considering the benefits, drawbacks, and the appropriate times to use these five modes, I chose joint interviews as the dyadic interview mode for this particular study. Joint interviews are commonly used when analyzing the interactions between dyads; they help to create a dyadic picture and shared discourse, allowing the researcher to learn about the dyadic relations of domination/being dominated (Eisikovits and Koren 2010). Because this study investigates how the interactions between married couples influence household hurricane preparedness, knowing and observing such realtime interactions between married couples is crucial.

After acquiring each couple's consent to participate in this study and determining demographic information (age and self-identified race/ethnicity), I asked questions about the couple's hurricane experiences, their current household hurricane-preparedness behaviors, their thoughts on the importance of household hurricane preparedness, the consideration of hurricane risk when choosing where to live, and any possible barriers to household hurricane preparedness. I also asked the couples about the household division of labor and the family decision-making process (for example, who usually decides where to travel and for how many days). Table 2 presents the full list of interview questions. Because I recognized that who actively answered the questions might be closely related to withinhousehold relations (that is, domination/being dominated, or decision makers within households for household issues/ hurricane preparedness), I allowed the couples to respond freely to my questions and did not ask the partners in a given couple to answer any of the interview questions individually, except for the questions on natural hazard experiences.

To better observe the real-time interactions between the couples in making decisions on household hurricane preparedness, I designed an activity for the couples. I asked the husbands and wives to create individual lists of the five most important hurricane-preparedness activities in their 
Table 2 Interview questions to determine household hurricane preparedness in Sarasota County, Florida, 2015

First, could both of you talk about your experiences with hurricanes? Could both of you also talk about your experiences with other kinds of natural hazards, such as floods, tornadoes, and earthquakes?

Could you talk about what kinds of preparation your family has undertaken in case of a hurricane?

Could you talk about whether you think some hurricane preparation activities should be done by men and others should be done by women?

Do you think hurricane preparation is important for your family? Why or why not?

Are there any barriers to hurricane preparation for your family? In other words, are there reasons why you don't engage in some hurricane preparation activities? What are those barriers?

Could you talk about the gendered division of labor in your family? I am thinking of who does the laundry, who cooks, who goes grocery shopping, etc. Where does this gendered division come from? Do both of you talk about this or did it just happen?

Could you also talk about who usually makes decisions about family activities?

In terms of family preparation for hurricanes, is the division of labor (that is, who does which tasks) similar to the division of labor for other family activities?

In terms of family preparation for hurricanes, is the decision-making process (that is, who makes which decisions) similar to other family divisions of labor or decision-making processes?

Did your family consider hurricane risks when choosing where to live in Sarasota County?

Activity

We will have a small activity right now. Both of you, please write down what you think the five most important hurricane preparation activities for your family are. The activities can be things that your family has done, or they can be things that you think are important but your family has not done. Do not discuss your answers with your spouse. Please be specific about the activities. For example, do not say, "Protect my family." Write down how you think it is important to protect your family

Please read your answers, wife first, then husband. Let me summarize the activities

Given that you have each selected five hurricane preparation activities and there is some/no overlap between your selections, together you could be said to have identified a total of $X$ different activities. Next, please determine how many of these $X$ activities with which you can both agree X-3 (or X-2 or X-1) in order to create a final list. In preparing this final list, each of you needs to cut at least one activity from your personal list. Each of you also needs to agree on this final list. Please discuss this with one another and provide me with a final list of X-3 (or X-2 or X-1) activities. I am especially interested in your discussion process, so I will need to listen to the discussion

Now that you two have completed this activity, could you two talk more generally about how decisions are made in your family?

Is there anything you would like to ask about me or about this research?

Is it possible for both of you to introduce me to two to three of your friends or neighbors who are married couples so that they might also participate in this interview?

households. These activities could be activities the members of their household had already completed or had yet to complete, as long as the person thought that they were important. I also asked the husbands and wives to be specific about the activities they named. For example, instead of saying that human security is important, one might indicate what one should do in order to protect humans, for example, plan an evacuation route. The partners were asked not to discuss their lists with each other as they were making them but, upon completion, were asked to read their lists and briefly explain why they thought the activities were important. I then combined the lists into a list of 10 activities (5 from the husband and 5 from the wife). Any overlapping activities were deleted (for example, if both partners had making a first-aid kit in their lists, the combined list had 9 activities). Then I asked the couple to discuss the combined list and remove 1-3 activities (depending on how many activities there were on the combined list) that both partners agreed were the least important hurricane-preparedness activities for their households. I told the couple to discuss the combined list in front of me. After the partners reached the agreement on the final list, the couple completed the activity by sharing their thoughts on each other's lists and on the final list (see Table 2 for the instructions for the activity).

All the interviews were recorded with two digital recorders. Verbatim transcriptions were created based on whichever audio file was of higher quality. I read through all of the transcriptions and classified them according to relevant key themes that emerged. Materials were then selected and presented in this study to support the discussion of the themes.

The couples interviewed had diverse backgrounds in terms of their ages (young adult/middle-age/elderly couples), household characteristics (with young children/with school-aged children/without children; rent/own; live in single-family house/other types of housing), country of origin (native-born/foreign-born), working status (both working/both retired/one working and one not working or retired), and hurricane exposure (home very close to shoreline/far away from shoreline, and in different hurricane evacuation zones). Nine of the 13 couples comprised 
partners who both self-identified as white. All but one of the couples lived in Sarasota County. The final couple technically lived in Manatee County, the county north of Sarasota County; but this couple lived just north of the Sarasota County border, and was located in an area that is part of the metropolitan Sarasota area. For this reason, this couple was included in the analysis. Interviews were conducted in English, except in the case of the Asian couple for whom the interview was conducted in Mandarin Chinese, my and the couple's native language. Pseudonyms are used throughout this study when referring to the interviewees. The characteristics of the interviewed couples are listed in Table 3.

\section{4 "The Boy Who Cried Wolf" and Household Hurricane Preparedness in Sarasota County}

Sarasota County is located on the southwest Florida coast. Its topography is very flat, rising from mean sea level along the coastline to approximately 100 feet in elevation inland (Campbell 1985). According to the 2010 census, the county has a disproportionately large elderly population, with

Table 3 Characteristics of the couples interviewed about household hurricane preparedness in Sarasota County, Florida, 2015

\begin{tabular}{|c|c|c|c|c|c|}
\hline ID No. of the Couples & Husband/Wife & Age & Race/Ethnicity & Interview date (all in 2015) & Length of interview (Approximate) \\
\hline \multirow[t]{2}{*}{1} & Alexander & 81 & White & 31 July & 30 \\
\hline & Ava & 79 & & & \\
\hline \multirow[t]{2}{*}{2} & Benjamin & 74 & White & 12 June & 60 \\
\hline & Bailey & 74 & & & \\
\hline \multirow[t]{2}{*}{3} & Caden & 72 & White & 11 June & 60 \\
\hline & Cora & 68 & & & \\
\hline \multirow[t]{2}{*}{4} & Daniel & 50 & White & 3 August & 40 \\
\hline & Dora & 44 & & & \\
\hline \multirow[t]{2}{*}{5} & Elijah & $60-65$ & White & 30 July & 50 \\
\hline & Emily & 62 & & & \\
\hline \multirow[t]{2}{*}{6} & Frank & 31 & Hispanic & 13 June & 60 \\
\hline & Francine & 30 & White & & \\
\hline \multirow[t]{2}{*}{7} & Gavin & 79 & White & 31 July & 50 \\
\hline & Grace & 30 & Mix & & \\
\hline \multirow[t]{2}{*}{8} & Henry & 29 & White & 13 June & 50 \\
\hline & Harper & 28 & & & \\
\hline \multirow[t]{2}{*}{9} & Isaac & 72 & White & 1 August & 50 \\
\hline & Isabella & 68 & & & \\
\hline \multirow[t]{2}{*}{10} & Jacob & 64 & White & 15 June & 80 \\
\hline & Janice & 59 & Asian & & \\
\hline \multirow[t]{2}{*}{11} & Kevin & 60 & White & 1 August & 40 \\
\hline & Kylie & 59 & & & \\
\hline \multirow[t]{2}{*}{12} & Lucas & 42 & White & 3 August & 50 \\
\hline & Leah & 44 & & & \\
\hline \multirow[t]{2}{*}{13} & Michael & 94 & Asian & 14 June & 30 \\
\hline & Mia & 73 & & & \\
\hline
\end{tabular}

No data was recorded for Elijah's age. Estimation of age based on his appearance and wife's age 
about $47 \%$ of the total population at least 55 years old. More than $60 \%$ of the households in the county are family households. Husband-and-wife families account for $48.8 \%$ of the total population, and only about $11 \%$ of the households have children at home, as would be expected in an older population.

Sarasota County has not had serious hurricane damage for many years. ${ }^{3}$ The last time a hurricane hit a populated area was when the Category 3 Pinar del Rio Hurricane struck in 1944 (FEMA 2005). Because of this, while many of the couples living in Sarasota County have had some experience with hurricanes from other places in which they had lived, none of them have hurricane experience in Sarasota County. Alexander and Ava, both of whom are retired and have been living in Sarasota County since 2006, talked about this lack of hurricanes:

Researcher: Have you had any hurricane experiences in the past?

Ava: Well, to tell you the truth, only from New York.

We had experience with Hurricane Gloria back then and it was nasty, but the only damage I had out of that was my shed. A tree fell against my shed and my insurance covered it, so thank God we were okay. No real damage.

Alexander: But since we're in Florida, we've never anticipated any hurricane, so far.

Benjamin and Bailey, both of whom are retired and moved to Sarasota County from Ohio, described what they had heard about the residents' overall experience with hurricanes:

Bailey: [...] but here, we have not, and the Smiths [note: their friends, who introduced me to this couple] probably told you, people tell us that there has never been a hurricane in Sarasota in years. They've had tornadoes spawn from it, they've had bad storms, but an actual hurricane has never hit.

Benjamin: Our friend across the way here has been here 6 years and he's never seen that [note: hurricanes].

While the couples had various levels of household hurricane preparedness, many of them were ill-prepared. A lack of a hurricane history is considered to be one reason

\footnotetext{
3 This paper was written and submitted to the journal for review before Hurricane Irma hit Sarasota County and the state of Florida in September 2017. The statement that Sarasota County had not been hit by a hurricane for many years and that the residents of Sarasota County lacked hurricane experiences were true when the article was written. The fact that Sarasota County was impacted by Hurricane Irma has provided an excellent opportunity to (re-)examine how intrahousehold and gender dynamics play roles in making decisions for actual hurricane preparedness.
}

why individuals may be underprepared for hurricanes. As Daniel, who had been living in Sarasota on and off for 35 years, indicated:

Researcher: Are there any specific reasons why you haven't thought about any kind of hurricane preparations?

Daniel: Probably because we've been lucky for so long that this area, for whatever reason, hasn't been hit for a long time and I think you just get lax.

Frank, a husband with young children, used the story of "The Boy Who Cried Wolf" to explain the county's hurricane history and residents' feelings about it:

Frank: I'm just thinking it's unfortunate in Florida because you hear about a hurricane that is going to come, but it never hits, so it's like, are you familiar with the old story, the children's story, "The Boy Who Cried Wolf"?

$[\ldots]$

Frank: So that's how the hurricanes are here because you hear there's a hurricane, and the weather people have nothing else to talk about, so when a storm comes they make a big deal about it. And then the storm comes and you're like, wow, okay, so a tree fell over, maybe, you know, there's a lot of wind and rain, but nothing happens. So then when the big one finally comes, nobody prepares for it. And so I feel like we kind of fall into that, as well [...].

\section{Intra-Household Dynamics and Household Hurricane Preparedness}

The couples discussed how their hurricane histories and hurricane experiences (or lack thereof) affected their levels of household hurricane preparedness, but other factors also proved to be crucial. This section explores how the interactions between husbands and wives, otherwise known as intra-household dynamics, also affect household hurricane preparedness.

Couples do not necessarily have similar ideas about household hurricane preparedness. Henry and Harper are a young couple with young children. Henry felt that household hurricane preparedness was important, but Harper did not:

Henry: Well, I try to make it important, but she's like "No, there's never hurricanes here. We don't need to prepare." I say we should probably have something here in case, because you never know. 
For Gavin and Grace, while Gavin did not think household hurricane preparedness was important, Grace thought it was:

Grace: I do. I want to dig a big basement with a real stone house with three-foot thick walls in the basement, and, yes, just in case and so the house would be on a hill, too. So we wouldn't be sinking at the same time. And some food in there, too, just in case.

Isaac and Isabella are a retired couple. Isabella talked about one of their experiences with hurricanes, suggesting that she and Isaac negotiated about whether to obtain plywood for the windows on their house:

Isabella: When we first moved here, there was going to be a hurricane. And I was very afraid and I talked to Isaac about it. And I said I think we need to get plywood to put on our windows and all of these things, and he thought that wasn't necessary. But he went along with me and he put up the plywood. Well it never did get bad, so we didn't need it.

When asked about who makes decisions on household natural hazard preparedness, couples usually said that they worked together. Janice is a stay-at-home wife who felt that teamwork was important in household hurricane preparedness:

Janice: It's teamwork. Especially when it comes to things like that: last minute, hurry. So we work together as a team-yeah."

Francine likewise stated that teamwork is how she and Frank make household decisions:

Francine: Yeah, it was a team effort. Cooperation. Absolutely. I think that's the way for us that it would be. I don't know in other situations; they separate things differently. But we work together pretty well, so I think that, yeah, a team effort.

I postulate that, for couples in which one person works but the other does not, the interactions between husband and wife regarding hurricane preparedness are different from those between a husband and wife who both work and share preparation duties. ${ }^{4}$ The interviews support that postulation. Frank and Francine were in a tropical storm a few years ago. Since Frank's job requires him to work during emergencies, Francine is responsible for preparing for emergencies at home.

\footnotetext{
${ }^{4}$ It is also likely that the interactions between husband and wife regarding household hurricane preparedness are different for couples in which one person works but the other does not and for couples in which both do not work. In this study, no interviewed couples exhibited the later pattern.
}

Francine: I mean, that was probably my first experience with it [...] He wasn't here. It was just myself and the baby, so I, I mean, I got like a folder filled with all of our important papers in case I needed to go anywhere and everything was kind of flooded. But it wasn't terrible. I kept calling him.

This mode of preparation, in which one person in a married couple is mainly responsible, may be more common in Sarasota County than in other places in the United States because Sarasota County has a huge elderly population and many people work in elderly-related industries. As the elderly tend to have special needs during emergencies, many people need to work during emergencies. Daniel, for example, runs an assisted-living facility, and he is unable to evacuate with his wife, Dora, and their children during hurricanes.

Daniel: I would have to go. Since I run an assisted living facility, I would have to be there-and that's a pretty strong building [...] Or I would have to evacuate the residents, which we're really not prepared for that. We're really not prepared for that.

\section{Household Division of Labor and Gendered Preparedness}

Intra-household dynamics influence household decision making regarding natural hazard preparedness. Closely related to intra-household dynamics are gender dynamics. During the interviews, it became clear that household divisions of labor are closely related to how husbands or wives determine the important elements of household hurricane preparedness. Gender dynamics became particularly visible during the exercise in which the couples were asked to participate.

The exercise showed that some couples had high levels of agreement regarding what is important. For example, both Isaac and Isabella listed as important preparing water and food, getting batteries and a flashlight, making sure the car is filled up with gas, and having cash on hand. Other couples, though, did not have many of the same activities on their lists. For instance, Frank and Francine only had one overlapping activity. The lists prepared by the couples are not provided here because it is difficult to summarize them. For example, some participants listed preparing water and food as separate activities, while others considered preparing all of the important supplies, including water, food, and other items, as one activity. What the participants did list, however, revealed important information regarding the gender dynamics of household natural hazard preparedness. 
At the outset, household divisions of labor are shown to be closely related to what couples think is important in terms of household hurricane preparedness. In many cases, a specific activity was mentioned by one of the partners but not the other. This difference was often attributable to the fact that the partner who mentioned the activity was responsible for that specific household task in everyday life. One example of this situation can be seen in the responses of Elijah and Emily. Emily is responsible for managing the important documents in their household, and she listed taking care of these documents and storing them safely as one of the five most important activities. However, Elijah had the following response to this:

Elijah: I had forgotten about the documents, and the papers, and all of that.

Another example is from Janice, who is responsible for cooking for herself and her husband Jacob:

Janice: I think food is the number one priority and, because I have to have gas to cook, number two is gas.

A third example is from Lucas and Leah, a couple with young children. Lucas is responsible for the yardwork. He had "remove all objects from the yard that could become a missile during the storm" on his list:

Leah: Oh, you're good. See, this is your job. Outside role. Good job.

Lucas also had "get batteries and other supplies" on his list, but Leah thought it was "funny" because Lucas "do[esn't] ever do that."

Another notable difference between the lists of husbands and wives was that more wives listed relational activities, including activities involving neighbors and children. For example, Grace said that she thought it was important to call their neighbors and suggest that they go to a nearby place that she thought would be safe (a high school that had a newly built building with a strong structure and that was in an elevated place), even when she was specifically asked to write down preparedness activities for her household. She also thought that it was important to prepare something like books or toys for children during emergency events. Leah put "talk to kids and keep them calm" on her list. A good summary of the differences in the listed activities was given by Lucas who, when talking about the differences between his list and Leah's list, said:

Lucas: I think I'm more task-oriented. Leah is also task-oriented but thinks of people.

\section{Discussion}

This exploratory study shows how intra-household dynamics and gender dynamics might affect household hurricane preparedness. The interviews conducted for the study indicate that the lack of a hurricane history in Sarasota County may help to explain why many households in Sarasota County may be underprepared for hurricane hazards. But we need to take intra-household and gender dynamics into account when considering how people make decisions regarding household natural hazard preparedness. Many couples consider household hurricane preparedness to be a joint process between husband and wife, but in many cases, partners do not have the same opinions about these preparations. As the case of Henry and Harper, among others, shows, one of the partners may think it is important to prepare while the other does not. Partners' job types also may influence preparedness decision making. In Sarasota County, a county in which many people work in elderly-related industries, and thus are very likely to be needed during emergencies, the negotiation between partners on household hurricane preparedness is particularly crucial.

The relationship between household division of labor and household hurricane preparedness is particularly important. The exercise that I conducted during the interviews revealed that the household hurricane preparedness activities that couples think are most important are closely related to each partner's unique role in the household. Specific activities were often listed by one of the partners but not the other, and this difference tended to reflect the everyday division of labor. Although the lists that the couples created were hard to summarize, a notable difference between the husbands and wives was that the wives tended to include more interpersonal activities, whether they were activities related to their children (for example, preparing toys or books) or other people (for example, asking the neighbors to evacuate).

Taking intra-household dynamics and gender dynamics into account when considering household natural hazard preparedness is important for both researchers and practitioners. Past studies have suffered from methodological inadequacies in collecting household preparedness data (Kirschenbaum 2006; Hung 2017). Given that household natural hazard preparedness is typically a joint decisionmaking process shared between spouses (Hung 2017), and given that partners do not necessarily agree with one another on preparedness, asking one person to answer questions about household natural hazard preparedness might result in incomplete or inaccurate information. For instance, the person who fills out the survey does not necessarily know all of the household-preparedness 
activities that have been undertaken because of his or her role in the household division of labor. It might thus be problematic to use the sociodemographic data of the person who fills out the survey to predict a household's overall level of preparedness.

Many studies have discussed gender differences in household natural hazard preparedness, with mixed results regarding who (male or female) exhibits higher levels of preparedness. Although the analysis in these studies might have been somewhat problematic, a possible explanation emerges from the current study for why females appear to have lower disaster preparedness levels than males. This perceived difference might lie in the fact that females tend to think more about interpersonal relationships, but those important relational preparedness activities, such as concerns about children's play or neighbors' safety, are often not included in the lists of preparedness items used in most household-level research. As illustrated in Table 1, most of the preparedness activities incorporated in such studies do not include the relational activities that females tend to think are important. One exception in Table 1 is Kim and Kang (2010), a study in which the investigators specifically set out to understand the relationship between interpersonal connections and household natural hazard preparedness. The likely reason that female natural hazard preparedness decision makers are considered to have lower preparedness levels than male decision makers is because the relational activities that females think are important-and thus activities in which females are likely to engage-are not among the preparedness activities listed in nearly all studies. What female decision makers may do in preparing for hurricanes might be not indexed in the lists of preparedness activities used in most studies, thus resulting in some research showing that females have lower preparedness levels than their male counterparts.

Future studies should focus on understanding the roles that different household members from various types of households play within the decision-making processes that relate to natural hazard preparedness (Ronan et al. 2015; Hung 2017). For example, Proudley (2008) described a case in which a mother consulted with her teenage children in order to make a decision about whether to evacuate during a bushfire. In addition to dyadic interviews, other types of qualitative research methods, such as focus groups, could be used to reveal household dynamics.

Actual household preparedness levels for hurricane hazards were considered during the interviews, and the levels of preparedness varied. Some couples talked exclusively about storing important documents in one place so that the documents were easy to locate and take during hurricane emergencies; other couples had completed many preparation activities, including structural preparedness activities like house renovations. The different levels of actual preparedness behaviors suggest that some of the effects of household dynamics on hurricane preparedness seen in this study were based on attitudes and hypothetical situations, while others were based on behaviors and actual interactions between husbands and wives. Future studies should take care to distinguish between the attitudinal effects and behavioral effects of household dynamics on household natural hazard preparedness.

\section{Conclusion}

It has been about a decade since the publication of Kirschenbaum's (2006) and Proudley's (2008) studies, both of which advocated for treating households or families as units of analysis in order to better understand the influence of intra-household and gender dynamics on natural hazard preparedness-related decision-making processes. However, these perspectives have yet to receive sufficient attention. The findings of this exploratory study confirm this research stream's significance for both scholars and practitioners, and can be used to inform data-collection processes and empirical evaluations of household natural hazard preparedness. More studies, especially ones with more rigorous research designs, larger sample sizes, different methodological approaches, and possibly more representative samples, are needed to provide a deeper understanding of the effects of household dynamics on household natural hazard preparedness.

Open Access This article is distributed under the terms of the Creative Commons Attribution 4.0 International License (http://crea tivecommons.org/licenses/by/4.0/), which permits unrestricted use, distribution, and reproduction in any medium, provided you give appropriate credit to the original author(s) and the source, provide a link to the Creative Commons license, and indicate if changes were made.

\section{References}

Allen, K.M. 2006. Community-based disaster preparedness and climate adaptation: Local capacity-building in the Philippines. Disasters 30(1): 81-101.

Baker, E.J. 2011. Household preparedness for the aftermath of hurricanes in Florida. Applied Geography 31(1): 46-52.

Basolo, V., L.J. Steinberg, R.J. Burby, J. Levine, A.M. Cruz, and C. Huang. 2009. The effects of confidence in government and information on perceived and actual preparedness for disasters. Environment and Behavior 41(3): 338-364.

Becker, J.S., D. Paton, D.M. Johnston, and K.R. Ronan. 2012. A model of household preparedness for earthquakes: How individuals make meaning of earthquake information and how this influences preparedness. Natural Hazards 64(1): 107-137.

Belch, G.E., M.A. Belch, and G. Ceresino. 1985. Parental and teenage child influences in family decision making. Journal of Business Research 13(2): 163-176. 
Blood, R.O., and D.M. Wolfe. 1960. Husbands and wives: The dynamics of married living. Glencoe, IL: Free Press.

Caldwell, K. 2014. Dyadic interviewing: A technique valuing interdependence in interviews with individuals with intellectual disabilities. Qualitative Research 14(4): 488-507.

Campbell, K.M. 1985. Geology of Sarasota County, Florida. Tallahassee, FL: Florida Geological Survey.

Carter-Pokras, O., R.E. Zambrana, S.E. Mora, and K.A. Aaby. 2007. Emergency preparedness: Knowledge and perceptions of Latin American immigrants. Journal of Health Care for the Poor and Underserved 18(2): 465-481.

Commuri, S., and J.W. Gentry. 2000. Opportunities for family research in marketing. Academy of Marketing Science Review 8: $1-34$.

Davis, H.L. 1976. Decision making within the household. Journal of Consumer Research 2(4): 241-260.

Davis, H.L., and B.P. Rigaux. 1974. Perception of marital roles in decision processes. Journal of Consumer Research 1(1): 51-62.

DeBastiani, S.D., T.W. Strine, S.J. Vagi, D.J. Barnett, and E.B. Kahn. 2015. Preparedness perceptions, sociodemographic characteristics, and level of household preparedness for public health emergencies: Behavioral risk factor surveillance system, 2006-2010. Health Security 13(5): 317-326.

Eisikovits, Z., and C. Koren. 2010. Approaches to and outcomes of dyadic interview analysis. Qualitative Health Research 20(12): 1642-1655.

FEMA (Federal Emergency Management Agency). 2005. Mitigation assessment team report: Hurricane Charley in Florida. FEMA Report No. 488. Washington, DC: FEMA.

Grothmann, T., and F. Reusswig. 2006. People at risk of flooding: Why some residents take precautionary action while others do not. Natural Hazards 38(1-2): 101-120.

Horney, J., C. Snider, S. Malone, L. Gammons, and S. Ramsey. 2008. Factors associated with Hurricane preparedness: Results of a prehurricane assessment. Journal of Disaster Research 3(2): 1-7.

Hung, L.-S. 2016. Gender, household decision-making, and hurricane preparedness. Ph.D. dissertation. Pennsylvania State University, University Park, PA, USA.

Hung, L.-S. 2017. Married couples' decision-making about household natural hazard preparedness: A case study of hurricane hazards in Sarasota County, Florida. Natural Hazards 87(2): 1057-1081.

Jóhannesdóttir, G., and G. Gísladóttir. 2010. People living under threat of volcanic hazard in southern Iceland: Vulnerability and risk perception. Natural Hazards and Earth System Sciences 10(2): 407-420.

Kang, S.K., and C.H.C. Hsu. 2005. Dyadic consensus on family vacation destination selection. Tourism Management 26(4): $571-582$.

Kim, Y.-C., and J. Kang. 2010. Communication, neighbourhood belonging and household hurricane preparedness. Disasters 34(2): 470-488.

Kirschenbaum, A. 2006. Families and disaster behavior: A reassessment of family preparedness. International Journal of Mass Emergencies and Disasters 24(1): 111-143.

Kohn, S., J.L. Eaton, S. Feroz, A.A. Bainbridge, J. Hoolachan, and D.J. Barnett. 2012. Personal disaster preparedness: An integrative review of the literature. Disaster Medicine and Public Health Preparedness 6(3): 217-231.

Lee, C.K.C., and S.E. Beatty. 2002. Family structure and influence in family decision making. Journal of Consumer Marketing 19(1): 24-41.

Lemyre, L., J.E.C. Lee, M.C. Turner, and D. Krewski. 2007. Terrorism preparedness in Canada: A public survey on perceived institutional and individual response to terrorism. International Journal of Emergency Management 4(2): 296-315.
Levac, J., D. Toal-Sullivan, and T.L. O'Sullivan. 2012. Household emergency preparedness: A literature review. Journal of Community Health 37(3): 725-733.

Lindell, M.K. 2013. Disaster studies. Current Sociology 61(5-6): $797-825$.

Lindell, M.K., and S.N. Hwang. 2008. Households' perceived personal risk and responses in a multihazard environment. Risk Analysis 28(2): 539-556.

Lindell, M.K., and R.W. Perry. 2000. Household adjustment to earthquake hazard. A review of research. Environment and Behavior 32(4): 461-501.

Lindell, M.K., and C.S. Prater. 2002. Risk area residents' perceptions and adoption of seismic hazard adjustments. Journal of Applied Social Psychology 32(11): 2377-2392.

Mahdaviazad, H., and G. Abdolahifar. 2014. Assessing household natural disaster preparedness in Shiraz, Iran, 2011: Results of a knowledge, attitude, and practices survey. Disaster Medicine and Public Health Preparedness 8(4): 349-352.

McGee, T.K., and S. Russell. 2003. "It's just a natural way of life..." an investigation of wildfire preparedness in rural Australia. Global Environmental Change Part B: Environmental Hazards 5(1-2): 1-12.

McIvor, D., and D. Paton. 2007. Preparing for natural hazards: normative and attitudinal influences. Disaster Prevention and Management: An International Journal 16(1): 79-88.

Morgan, D.L., J. Ataie, P. Carder, and K. Hoffman. 2013. Introducing dyadic interviews as a method for collecting qualitative data. Qualitative Health Research 23(9): 1276-1284.

Morris, S.M. 2001. Joint and individual interviewing in the context of cancer. Qualitative Health Research 11(4): 553-567.

Mottiar, Z., and D. Quinn. 2004. Couple dynamics in household tourism decision making: Women as the gatekeepers? Journal of Vacation Marketing 10(2): 149-160.

Mulilis, J.-P. 1999. Gender and earthquake preparedness: A research study of gender issues in disaster management: differences in earthquake preparedness due to traditional stereotyping or cognitive appraisal of threat? Australian Journal of Emergency Management 14(1): 41-50.

Neuman, W.L. 2000. Social research methods: Qualitative and quantitative approaches, 4th edn. Boston: Allyn \& Bacon.

O'Brien, P.W., and P. Atchison. 1998. Gender differentiation and aftershock warning response. In The gendered terrain of disaster: Through women's eyes, ed. E. Enarson and B.H. Morrow, 173-180. New York: International Hurricane Center. Laboratory for Social and Behavioral Research.

Parsizadeh, F., M. Ibrion, M. Mokhtari, H. Lein, and F. Nadim. 2015. Bam 2003 earthquake disaster: On the earthquake risk perception, resilience and earthquake culture-Cultural beliefs and cultural landscape of Qanats, gardens of Khorma trees and ArghE Bam. International Journal of Disaster Risk Reduction 14(Part 4): 457-469.

Paton, D. 2003. Disaster preparedness: A social-cognitive perspective. Disaster Prevention and Management 12(3): 210-216.

Paton, D. 2014. Risk, resilience, and readiness: developing an allhazards perspective. In Hazards, risks, and disasters in society, ed. A.E. Collins, J. Samantha, B. Manyena, and J. Jayawickrama, 307-323. Amsterdam: Elsevier.

Paton, D., B.F. Houghton, C.E. Gregg, D.A. Gill, L.A. Ritchie, D. McIvor, P. Larin, S. Meinhold, et al. 2008. Managing tsunami risk in coastal communities: Identifying predictors of preparedness. Australian Journal of Emergency Management 23(1): 4-9.

Paton, D., G. Kelly, P. Burgelt, and M. Doherty. 2006. Preparing for bushfires: Understanding intentions. Disaster Prevention and Management: An International Journal 15(4): 566-575. 
Paton, D., L. Smith, and D. Johnston. 2005. When good intentions turn bad: Promoting natural hazard preparedness. Australian Journal of Emergency Management 20(1): 25-30.

Proudley, M. 2008. Fire, families and decisions. Australian Journal of Emergency Management 23(1): 37-43.

Ronan, K.R., E. Alisic, B. Towers, V.A. Johnson, and D.M. Johnston. 2015. Disaster preparedness for children and families: A critical review. Current Psychiatry Reports 17(7). https://doi.org/10. 1007/s11920-015-0589-6.
Russell, L.A., J.D. Goltz, and L.B. Bourque. 1995. Preparedness and hazard mitigation actions before and after two earthquakes. Environment and Behavior 27(6): 744-770.

Thompson, L., and A.J. Walker. 1982. The dyad as the unit of analysis: Conceptual and methodological issues. Journal of Marriage and Family 44(4): 889-900.

U.S. Census Bureau. 2010. Profile of general population and housing characteristics: 2010. 2010 census summary file 1. https:// factfinder.census.gov/faces/nav/jsf/pages/searchresults.xhtml?re fresh=t. Accessed 1 Jan 2017. 